\title{
A NARRATIVE APPROACH TO BOTH TEACHING AND LEARNING ABOUT DEMOCRACY WITH YOUNG CHILDREN: A THEORETICAL EXPLORATION
}

\author{
Maila Dinia Husni Rahim ${ }^{1}$, Husni Rahim ${ }^{2}$ \\ Universiti Putra Malaysia (UPM) ${ }^{1}$, State Islamic University (UIN) Syarif Hidayatullah Jakarta ${ }^{2}$ \\ Email: mailadiniahr@gmail.com \\ Naskah diterima : 17 November 2015, direvisi : 21 November 2015, disetujui : 27 November 2015
}

\begin{abstract}
As adults, we often believe that children are only interested with games and children's 'stuff'. However research has shown that children do indeed show a greater interest in the world around them, including about politics, elections, and democracy. If we need to teach children about democracy, what are the best methods of teaching democracy to young children? Narrative is considered as an effective medium to convey messages to children and discuss hard subjects. This paper is a theoretical exploration that looks at the narrative approach to teaching and learning about democracy with young children. The researchers has used a literature review to look at why narratives should be used, what narratives should be used and how to use narratives.
\end{abstract}

Keywords: narrative; democracy education; young children

\section{Abstrak}

Sebagai orang dewasa, kita sering percaya bahwa anak-anak hanya tertarik dengan permainan dan urusan anak-anak saja. Namun penelitian telah menunjukkan bahwa anak-anak memang menunjukkan minat yang lebih besar di dunia di sekitar mereka, termasuk tentang politik, pemilu, dan demokrasi. Jika kita perlu mengajarkan anak-anak tentang demokrasi, apa metode terbaik pengajaran demokrasi anakanak? Narasi dianggap sebagai media yang efektif untuk menyampaikan pesan kepada anak-anak dan mendiskusikan materi pembicaraan yang sulit. Tulisan ini adalah eksplorasi teoritis mengenai pendekatan narasi untuk belajar dan mengajar tentang demokrasi dengan anak-anak. Peneliti menggunakan kajian literatur untuk melihat mengapa narasi harus digunakan, narasi apa yang harus digunakan dan bagaimana menggunakan narasi.

Kata kunci: narasi; pendidikan demokrasi; anak-anak

Pengutipan: Rahim, M. D. H., Rahim, H. (2015). A Narrative Approach to Both Teaching and Learning About Democracy with Young Children: A Theoretical Exploration. SOSIO DIDAKTIKA: Social Science Education Journal, 2(2), 2015, 136-146. doi:10.15408/sd.v2i2.2809.

Permalink/DOI: http://dx.doi.org/10.15408/sd.v2i2.2809 


\section{A. Introduction}

"Mother, who did you select? Father, who did you choose? But, why did the candidate that mother chose lose? Ah mother, you should not have chosen him." 2014 was the year of the Democratic Party (Pesta Demokrasi) in Indonesia. Yet interestingly, it was not only adults who went wild with the people's party (pesta rakyat). Children also participated in this political euphoria. The first author's 6-year old son raised the questions above; we are sure the same questions have been asked by many children to their parents and teachers. The general election and presidential election is like a competitive game in the eyes of children. There are winners and losers. There are tricks and traps, the winner is the one who has good strategy, or is it just simply because of luck? The first author's son thought that she had not voted for the elected president, so she therefore she had lost the game. He said that his friend's parents had chosen the right candidate, and therefore they had won. "You lose mom...Na, na, na (rhyming). You shouldn't have voted for him!”.

This presidential election moment could be the first democratic lesson for young children. They questioned it, they were aware of the situation, they felt the tension. In some houses, parents chose different candidates. There are cases where families were divided because of political choices and marriages ended because of political tension and discussions at home. The Chairperson of the Central Board of Women of the Nadlatul Moslem Cleric (NU) and now the Minister of Social Welfare, Khofifah Indar Parawansa said that the number of divorces triggered by political differences has increased. She added, in 2008, divorces triggered by political differences within the family was ranked as number 13. "In four years, the divorce rate because of this political election has increased sharply," she explained. "It happened in the big cities. The numbers can penetrate even $70-80$ percent." ${ }^{\prime \prime}$ She clarified the data shows that the political climate has entered into the household. If we look at the statistics

\footnotetext{
1 Khofifah Indar Parawansa, "Beda Politik Picu Suami-Istri Cerai", in http://www.tribunnews.com/pemilu-2014/2014/06/18/beda-politik-picusuami-istri-cerai. Retrieved [21 November 2015].
}

in 2009, where there was both an Election and a Presidential Election. In that year, 402 cases of divorce were reported because of the political situation. While in 2010, when the political situation had returned to normal, political divorces decreased to 334 cases. $^{2}$

Data released by the Religious Courts of divorces throughout Indonesia, showed that there were 285,184 divorces in 2010, 334 of which were caused by differences in political views. The percentage is less than a percent, but it remains striking. ${ }^{3}$ Moreover, of that number, the largest proportion was reported in East Java, with a total of 221 couples divorcing. Meanwhile, West Java reported 51 cases of divorce. Meanwhile, Central Java recorded fewer divorces because of different political views with 36 cases. In Riau 13 couples were reported to have divorced due to politics. While in South Sumatra, South Sulawesi, and Papua, two cases were reported respectively. While in Aceh, Bengkulu, Yogyakarta, West Kalimantan, East Kalimantan and Central Sulawesi and West Nusa Tenggara there was one case of divorce each. This divorce rate data shows that many people really look forward to the process of appointing the next leader and feel a responsibility to join the election and decide upon the direction of the country in the future. Some people get divorced because of having different political views from their spouses. The tense discussion among parents undoubtedly attracted their children's attention. What is this 'game' that my parents watch and talk about almost whole day? In the morning during breakfast, the TV constantly on the news channel, discussion in the car on the way school and so on until night time before bed. The kids may think, I have never been involved in a game so intense like this before.

During every election season, we see signs, bumper stickers, and advertisements for political candidates and parties everywhere. Streets are filled with colorful flags from various political parties. Television programs are also filled with campaign, pictures, photos, and

2 Tinggi, Cerai Karena Beda Pandangan Politik", Available: http:// www.jpnn.com/read/2011/08/04/99779/Tinggi,-Cerai-Karena-Beda-Pandangan-Politik-. Retrieved [21 November 2015].

3 The Religious Courts (Detik, 2011). 
shows on the elections and the parties. An adult competition, to win the election, yet it is a party for the masses. We can't expect our kids not to be influenced by the whole media blitz. In the last election, the first author and her husband had no political differences; however they still had disagreements and arguments about the candidates and other issues related to the election. Their son listened to them carefully, and sometimes even joined in the discussion with his own thoughts. "What will be the prize? Why don't you become the candidate?".

If we think that children are only interested in video games and doing 'kids stuff', we might be wrong. KidsHealth.org asked more than 2,000 kids and teens aged 8 to 14 years old throughout the U.S. on what the kids thought about the 2012 presidential elections and how they might affect them, if at all. Suprisingly, 75 percent of the kids and 79 percent of the teenagers answered "yes" when asked whether they thought that the outcome of an election would change their lives. Nearly half of the teens surveyed said that they believe they had at least some influence on their parents' choice of candidate. ${ }^{4}$

Last year, we interviewed a headmaster from an Islamic kindergarten in a suburb of Jakarta. The interview was actually about how they introduce values to children at school. He told a story about how the school had set up a socio drama on democracy in Indonesia, more specifically on presidential elections related to the recent election in Indonesia. He explained, "We made a little country in the school, pretending there was a real election of a president. We created parties; the parties included Rambutan, Jeruk, and Durian. We named the political parties based on fruit. Then, we selected the candidates, and appointed teachers to become advisors for each candidate and party. The parties and candidates created campaign, signs, and political ads on paper that they put on the walls in the playing room. It was a real election. Children were fully involved and they related the experience with the real presidential election that the adults talking about." The

\footnotetext{
4 "Talking Politics: What to Say to Your Kids", Available: http://kidshealth.org/parent/positive/family/voting_banner.html. Retrieved [20 November 2015].
}

story of the kindergarten headmaster and also the opinion of the first author's son, showed that even children younger than eight are aware of political issues and discussions around them. They have opinions and are aware what is going on in their own way of thinking.

Knowing that kids think about democracy, we should think about what possible way discussions of these issues could be useful for children. One thing that we could think about, as a parents, is that we see it is beneficial to promote learning and develop critical thinking skills in children, and also this is the most opportune time to clear up any misconceptions the children may have or calm any fears about the future. Another thing, it is widely believed that children learn social behavior through the process of observation learning-through watching the behavior of another person. ${ }^{5}$ What children see and hear from the parents at home, would therefore influence their behavior and social interaction. Children could possibly learn to be responsible citizens, get involved in establishing the future of the country by participating in general elections and presidential elections. Moreover, the UN convention on the rights of the child, mentioned that children should experience and internalize values for human rights, and develop their own opinions and moral responsibility.

Children also learn to be sportive in competition; in an election, there must be the elected and the unelected. Children learn about the world, the issue of democracy, and education about the world is practical and useful for children now and in their future, and it is should be one of the goals of education. Perkins asserted that the goal of education is to engage students with "knowledge that does not sit there but functions richly in people's lives to help them understand and deal with the world". ${ }^{6}$ In the formative early childhood years, education plays an important role in assisting the future adult citizens of the world to be moral and respectful individuals.

\footnotetext{
5 A. Bandura, Social Learning Theory (NJ: Prentice, Englewood Cliffs, 1977).

6 D. Perkins, Smart Schools: From Training Memories to Educating Minds (Free Press, 1992), p. 5.
} 
Teaching Democracy should be about making the subject as functional and applicable as possible. Democracy should not be understood as a hard, complicated and adult subject. Epp and Beaulieu, cited by Hearton and Lemisko, said that the common fallacy perpetuated in the Western curriculum is to examine democracy in the classroom as merely a monolithic entity, as a serious subject that discusses the government of the people, by the people for the people. Then the discussion is simplistic and the term of democracy becomes vague. $^{7}$ The term labels those countries that are democratic as good countries and those that are not as bad ones. Then this makes it difficult for students to understand what democracy is. In kindergarten, what discussion will be initiated in class?.

The next question concerns what is the best way to teach children about democracy? The example above from the kindergarten in Jakarta, could be one of many ways. The kindergarten introduced the issue through socio drama, we could also use discussion, or maybe watching news and movies, or inviting a political figure to share their ideas, and in this paper, we will discuss a theoretical exploration on the use of narrative approach in both teaching and learning about democracy: So, why narrative? What is narrative? How is narrative effective?

\section{B. Discussion}

It is important to firstly define the term democracy as used in this paper. The concept of democracy might be ambiguous, as there are many ways to understand and explain it. Emilson stated in an educational context that there are two dominant discourses on democracy: one refers to teaching democracy and the other to lived democracy. In this paper, following Emilson, we focused upon lived democracy as expressed in communication. Communication here is viewed as a condition for democracy and specifically characterized by the meaning, making and mutual understanding between the communication participants. ${ }^{8}$

M. Epp, \& K. Beaulieu, Democracy in the Classroom. In T.A. Hor ton \& L. Lemisko (Eds). Educator to Educator: Unpacking and Repacking Generative Concepts in Social Studies (Rotterdam: Sense Publishers, 2015), p. 93-104.

8 A. Emilson, Democracy Learning in A Preschool Context. In N,
Emilson described democracy education for young children as an opportunity to encourage children to make their own choices, take initiative, solve problems, think divergently, and to take risks. In the classroom setting, democracy is related to three values: participation, influence and negotiation. ${ }^{?}$

So, the theoretical exploration on how narrative approaches can be used as a method of teaching and learning democracy in kindergarten level, will be an exploration on the use of narrative, kind of narrative and how to use the narrative in teaching and learning to kindergartners about participation, influence and negotiation. The why-aspect is to answer the question about the legitimacy and on the one hand, democracy as a learning content is not stated as one subject or topic discussion in curriculum of kindergarten in Indonesia, but it is discussed in the social and moral education program or as hidden curriculum. The whataspect, partly refers to the question about the selection of the content, while the how is to answer the question on how democracy should be communicated in narrative.

\section{Why Narrative}

Narrative is believed to be one of the most effective mediums of communication, and is used to convey messages, such as the issue of democracy which is useful for the formation of a positive character in children. Through stories, advice can be delivered in a fun way, which is easily understood by children. Democracy is often understood as adults' business, complicated, abstract discussion. However, children do show their interest in human issues; even political issues. Early childhood is a crucial stage in terms of a child's physical, intellectual, emotional and social development. Mental and physical abilities progress at an astounding rate and a very high proportion of learning takes place during the stage from birth until the child is six years old. Therefore early childhood education is clearly very important. Early childhood education should support children's development and

Pramling \& I.P. Samuelson (Eds). Educational Encounters: Nordic Studies in Early Childhood Didactics (New York: Springer, 2011), p. 157-172.

A. Emilson, \& E. Johansson, The Desirable Toddler in Preschool: Values Communicated in Teacher and Child Interactions. In D. Berthelses, J. Brownlee, \& E. Johansson (Eds.), Participatory Learning in The Early Years: Research and Pedagody (New York: Rotledge, 2009) 
meet the children's needs. It's focus should not only be on one aspect of development, as often people tend to focus only on cognitive development, schools should also pay attention to other aspects of children's development. Early childhood is the foundation for further development. Early childhood education is significant in affecting the children's progress in their next stage of education and in their future life. It is a foundation. One important aspect that schools usually neglect is the character building of their students. Character here also includes how children participate, be part of development, be a good citizen, and know the importance of their voice. What young children learn from their early education will be the seed of who they are later on. Teaching young children democracy will be the seed to ensure they become good, responsible citizens in the future.

Kilpatrick, Wolfe, \& Wolfe argued that the characters in a story help children to understand problems in different perspectives; to encourage children to share; and build a sense of empathy. Telling or reading narratives is a particularly good way to teach children realistic thinking as children can see in the stories how people solve their problems. Telling or reading narratives on democracy, such as stories that highlight the characters' agreement or disagreement toward certain issues or events in public, might help children to understand that people have different perspectives, and that this is okay, to build confident children who are not afraid to state their mind, and are not afraid of disagreements. ${ }^{10}$

Bennet and Sanchez argued that heroic stories will inspire kids to do good things. A hero who achieves justice will inspire children to do good, protect their property, and be brave. ${ }^{11}$ Anderson \& Groft believed that children can learn from stories because stories provide experience. $^{12}$ Stories are a portrayal of life and the mind in the form of words. Stories

10 Kilpatrick, W., Wolfe, G., \& Wolfe, S.M., Books that Build Character: A Guide to Tecabing Your Child Moral Values (New York: Touchstone, 1994).

11 Bennet, W., Books of Virtues, (New York: Simon \& Schuster, 1995). Sanchez, T.R., "Using Stories about Heroes to Teach Values", ERIC Clearinghouse for Social Studies/Social ScienceEducation (kota: penerbit, 1998), Available: http://files.eric.ed.gov/fulltext/ED424190.pdf. Retrieved [18 November 2015]

12 Anderson, W., \& Groft, P., A New Look at Children's Literature (Belmont, CA: Wadsworth Publishing Co., Inc, 1972). influence the way children think and behave. Through narratives, children experience many different occasions and events, in a wide variety of different places and situations. Children get inspired from the story to learn how the characters solve problems. Children like to hear or read stories over and over again and it makes them remember details in the stories. This repetition with the combination of the children's imagination make stories one of the best ways to influence thinking. When we want to teach children participation, influence and negotiation, or democracy, we need to bring up the topic more than one time. Children learn better with repetition.

DeVries and Zan (1994) thought stories could be an effective medium to discuss the moral dilemmas and that the discussions could even empower children to develop their rational capacity. ${ }^{13}$ Stories discuss situations and events that maybe the readers have never experienced before, problems they may never have had. They learn from the obstacles faced by the characters in the stories, how they deal with it and find solutions. They learn the consequences of doing certain things and rewards for doing good things. Moreover, many issues related to democracy are dilemmatic, and require decisions to be made. When one party or candidate loses in an election, how should you react, what about the winner, how should they react, and how about the supporters, what should they do?

Noddings argued that stories of human relationships can inspire children to put moral action before any other actions. Interactions among characters in the stories inspire children about how to interact with others in real life. They learn how relationships either fail or are successful. They learn that people are different and need to respect them. ${ }^{14}$ Applebee (1978), Ricceur (1984), Karolides \& Rosenblatt (2005), and Weatherford (2000) argued that stories provide children with opportunities for linking their prior knowledge and personal experience with the experience of the characters in the story. ${ }^{15}$ By linking this, they make connections

\footnotetext{
13 DeVries \& Zan, Moral Classroom, Moral Children: Creating a Constructivist Atmosphere in early Education (New York: Teachers College Press, 1994).

14 N. Noddings, Starting from Home: Caring \& Social Policy, (Los Angeles: University of California Press, 2002).

15 N. Noddings, op. cit.
} 
and put themselves in the characters' situation. It teaches both sympathy and empathy.

Moreover, Nobes and Pawson stated that children can learn and understand social rules and authority from storybooks. They learn how characters in the story fail to follow the rules and what the consequences ar for them and others. They learn that with democracy, participation, influence and negotiation are all important. Therefore, these three values all need to be learnt. When we have disagreements, we learn to influence others to support us and negotiate what is the best way. ${ }^{16}$

Narratives are promising to become an effective medium of teaching and learning democracy at kindergarten level. Narratives can be used in promoting children's moral development. Narratives promote moral reasoning, knowledge, character, sensitivity, and character. McGinn observed that, "Fictional work can make us see and feel good and evil in a way that no philosophical tract can-unless it takes on board what literary works achieve so well". ${ }^{17}$ Narrative stories help children define who they were, are, and hope to be. These stories have the potential to open a child's eyes so that they can see and understand the world around them more clearly. Stories provide experience. Stories help children gain insight into the significance of those experiences. Stories are the portrayal of life and mind through language. ${ }^{18}$ Stories are memorable; their recall may be triggered by either a monumental event or some seemingly minute or inconsequential detail. $^{19}$ Stories provide opportunities for linking our prior knowledge, for connecting a personal experience with the experience of the characters in the story. Karolides and Rosenblatt argues that the reader actively creates meaning from a book through a transactional process in which the reader makes sense of the text by drawing upon his or her own previous experiences and ideas. ${ }^{20}$ Applebee sees stories as providing children with additional experiences,

\footnotetext{
16 Nobes, G., \& Pawson, C, Cbildren's understanding of Social Rules and Social Status (Merryl-Palmer Quarterly: 49: 1, 2003), p. 77-99.

17 McGinn, C. Ethics, Evil and Fiction, (Oxford University Press, 1997), p. 176

18 Anderson, W., \& Groft, P. op. cit.

19 Weatherford, C.G. Tales that Teach: Children's Literature and Service Lean ing (Columbia: National Dropout Prevention Center, 2000).

20 Karolides, N.J., \& Rosenblatt, L.M. Theory and Practice: An Interview with Louise M. Rosenblatt. In L. Rosenblatt (Eds), Making Meaning with Texts: Selected Essays (Portsmouth: Heinemann, 2005).
} Lieberman, as cited by Joosen said that from reading stories, children learned behavioral and associational patterns, value systems, and how to predict the consequences of specific acts or circumstances. ${ }^{22}$ Ricceur viewed stories and narrative as not just something we say or listen to, but something we do or experience. ${ }^{23}$ Brune argued that narrative is concerned with "intention and vicissitudes." He compared it to moral life that is also concerned with intention and vicissitudes, with human action and with human possibilities within the world of action. ${ }^{24}$ These researchers advocate the use of literature to help meet social and moral educational goals. Stories are recognized as having the potential to contribute significantly to the critical thinking of children and adults. Stories are effective in providing role models, giving opportunities to discuss moral dilemmas, and having the potential to contribute significantly to the teaching and learning of democracy for young children.

\section{What Narrative}

The Children Book Council (1995) gave suggestions on how to pick narratives for children aged 4-6 years old (kindergarten age children). Children at this age group enjoy books depicting familiar objects and experiences that are enjoyable to children in this age group. The children at this age also like to listen to complex texts with good rhythm and effective word repetition. They also love to have constructive fun with toy-like books that either pop-up, move or provide other excitement or amazement. ${ }^{25}$ On the cover of the books, sometimes it is indicated the age level or grade level for which the publishers of the books believe is the most suitable. The Children's Council suggested that we should not worry about choosing a book suggested for someone older than the child. It is going to be intriguing for their mind and they learn more vocabulary. Children are moving

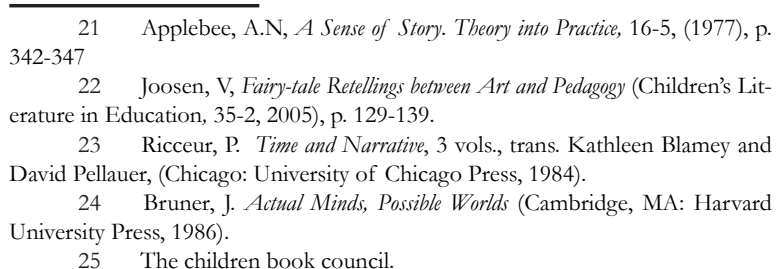


easily with books with great artwork. Interesting stories are easy to understand, beautiful, wellillustrated books, children love repetition, they will love to repeat books that have good illustration. Some children love classic books while others find a contemporary book more appealing. In the classroom we should mix the use of these books. Teachers should be aware when the children enjoy or do not enjoy the stories. A fine book is not necessarily the most expensive book on the shelf. We should carefully choose the books for children; choose a well written and appropriately designed book. A book is an unlimited investment in the human mind and spirit. Book selection deserves thoughtful attention.

What book should we select that best teaches about participation, influence and negotiation or in summary as democracy? We looked at the Gramedia website and focused specifically at books on democracy for children. We found nothing specifically about democracy. Gramedia is the largest bookstore and publisher in Indonesia. Since this paper only discusses the theoretical exploration on the use of narrative of education democracy at kindergarten, We did not go into the field to collect empirical data. So, We decided to browse what books are suggested to teach democracy. We used the keywords, 'children's books on democracy'.

We found a Canadian site, a parenting site more specifically, based in Montreal. Canada had just elected and inaugurated their prime minister this year. ${ }^{26}$ Di Domenico wrote in the site:

On Oct. 19, Canadians will vote in the 42nd federal election. In the last election, voter turnout was a dismal 61 per cent. For those of us who live in a democratic society, it's easy to take for granted the fact that we can elect our government, support any political party we choose, express dissent and enjoy equal rights for all citizens. This campaign is an ideal time to start teaching children about their civic responsibilities so that when their turn to vote arrives, they will be ready and eager. ${ }^{27}$

\footnotetext{
26 Di Domenico, Books that Teach Kids about Democracy. (2015, Available: http://www.montrealfamilies.ca/Montreal-Families/October-2015/Books-thatteach-kids-about-democracy/. Retrieved [21 November 2015]

27 Di Domenico, op.cit.
}

The site provides suggestions on how parents can read stories on elections to children. It is stated that the number of participants in the previous election was in decline. By teaching democracy and the importance of participation, it will inspire children to later become responsible citizens who will give their voice and participate in deciding the destiny of the country. For kindergarten children, the site suggested the book entitled, Otto Runs for President. This picture book is written by Rosemary Wells. Di Domenico wrote the summary of the book, "Elections are happening at Barkadelphia, a school populated by dogs. A popular poodle named Tiffany joins the race, as well as a jock bulldog named Charles. They have a lot of resources to make splashy campaigns but they don't seem to care much about what their voters want. Otto may be more of a mutt and not your typical candidate, but he decides to throw himself into the race. As the only candidate who actually asks his peers about their interests and concerns, to his surprise he wins the election. The book guides children through the electoral process and teaches them about the responsibilities of elected officials. Children will enjoy seeing dogs participate in elections in a school setting." 28 The storybooks personify animals, and picture them as candidates and voters. Children learn about simple electoral systems from the story. Wells highlights some of the pitfalls of democracy, including the challenges of keeping election promises, as Otto learns.

A US based website named Forever Families, has a list of books on democracy for young children and older children. This "provides practical and scholarly sacred information for strengthening individuals, marriages, and families." This organization is sponsored by the School of Family Life at Brigham Young University. For young children aged 4-8 years old, the site suggested these books:

a. A Boy Called Slow, by J. Bruchac (1994). New York: Philomel Books.

b. The Story of Ruby Bridges, by R. Coles (1995). New York: Scholastic.

c. Eleanor, by B. Cooney, B. (1996). New 
York: Viking.

d. Peaceful Protest: The Life of Nelson Mandela, by Y.Z. McDonough (2002). New York: Walker and Company.

e. Mufaro's Beautiful Danghters: An African Tale, by J. Steptoe (1987). New York: Lothrop, Lee \& Shepard Books.

The selections of book are more contemporary stories that are familiar with children' lives. The books are not specifically about elections, but books about decision making, negotiation, and participation in daily lives.

The Canadian site specifically gave opinions on how electoral events occurred, while the Forever Families did not. There is no data yet on what kind of books had a greater influence upon children. But I believe variation is important. So, therefore teachers should not just stick to one type of story.

\section{How Narrative}

Friedrich Frobel $\left(19^{\text {th }}\right.$ century) considered children to be similar to plants, which must have the rights conditions to grow, and he felt that caregivers should create an environment which enables a child to develop his/her inherent natural abilities. Schooling is not only a means for the acquisition of scientific knowledge and life skills, but it is also responsible for the moral education of students. In the literature, teachers have been depicted as significant contributors to the social and moral development of their students. ${ }^{29}$ Teachers play an important role in making meaning of what democracy is and also teach children how to participate, influence and negotiate during their social lives.

Some time ago, we conducted a prior study that was aimed at examining how students digest the messages in stories. From this simple study, we concluded that teachers have a very important role in helping students understand the story and the message of the story. Most of the young children in kindergarten are not able to read yet, so the teacher will read/tell the

29 Revell, L., \& Arthur, J, Character Education in Schools and the Education of Teachers (Journal of Moral Education, 36:1, 2007), p. 79-92. story to them. The way they tell the story will help/not help children to understand the story. It is not only just reading, but also intonation, mimicking, voice pitch, and where to pause, which will all affect the children's understanding. To be able to present the story well takes good preparation. In addition, the flexibility and creativity of a storyteller, presentation techniques, and storytelling skills can only be mastered with experience and training. Certain exercise routines are needed. Teachers in kindergarten are expected to present the tale in an interesting and fun way. Children will give the most attention when teachers tell stories well and the story is interesting, so that the children can understand the story and the message contained in it. The teacher's understanding of the story is also vital here. Teachers should prepare themselves before storytelling. They must understand the storyline, the characters in the story, the plot and also the moral of the story.

The teachers' views about democracy will play a major role in the understanding of what will be the theme and the message of the story. How the teacher interprets democracy will be reflected in the way they deliver the story's message. Teachers vary in their perceptions on democracy. However, it is important that teachers have self-efficacy on the subject they teaches. Midgley, Feldlaufer \& Eccless stated that students are more academically motivated in classrooms with teachers of high instructional self-efficacy. ${ }^{30}$ They should understand what and how they teach the subject. Students will enjoy a greater benefit from having teachers with high self-efficacy. ${ }^{31}$ The self-efficacy of teachers in teaching about democracy in kindergarten will have the ability to understand the concept of democracy and know the best method to teach it. Yet one vital thing that should also be considered is how teachers view democracy.

Teaching democracy might not be effective. Cotton reviewed many studies about teaching children democratic citizenship, and she pointed to several factors that make teaching and

30 Midgley, C., Feldlaufer, H., \& Eccless, J.S. Changes in Teacher Efficacy and Student Self- and Task-Related Beliefs During the Transition to Junior High School (Journal of Educational Psychology 81 (2), 1989), p. 247-258

31 Ross, J.A, Teacher Efficacy and the Effect of Coacbing on Student Achievement (Canadian Journal of Education, 17 (1), 1992), p. 51-65. 
learning become ineffective. First, is a lack of meaning, children were given isolated facts on democracy and weren't taught how to actually apply them in real life situations. Second, there is a lack of focus on the rights presented in the story. Children were not taught about the individual freedom granted by the constitution, such as freedom of speech. The process of teaching and learning is passive. Children only looked at or read from a book, instead of actually thinking and developing their own skills. In the classroom, some teachers play safe by avoiding the controversial topics. Topics that usually interest children were avoided, denying children the opportunity to think critically and make up their own minds when presented with contradictory evidence. ${ }^{32}$

\section{Conclusion}

Narrative could be one of the possible effective mediums of teaching and learning about democracy for young children in kindergarten. The kind of story and the how the story is presented is important in the success of the method of teaching and learning using narrative approach. This paper is only looking at theories. Further research is therefore needed. Research in the legitimacy of using narrative approaches, empirical studies on what narratives have a suitable message concerning democracy for kindergarten children and on how to convey or communicate the need and importance of education on democracy. We need also to look at the effect and impact of teaching democracy from an early age to the development of characters who are effective citizens of the country.

Democracies are built on the belief that we should participate, make choices, get opportunities, get individual freedom and should work together to make each other's lives better. The democracy that we talked about in this paper is not specifically the Democratic Pancasila that Indonesia has relied on. We talk more about the general concrete teaching of democracy to young children, not the teaching of the concept of democracy but more on living with democracy and democracy in daily lives. If we want to maintain our democratic society, it is important we teach children to be good citizens not just teaching them to obey the laws, but also to be responsible with their actions. We teach them freedom with responsibility, freedom that will not harm others. In the globalized world, learning about democracy is not only limited to a nation, we are global citizens, we should understand that we are part of the world community, so then we should participate, giving voice to make our lives together be better. Children learn about it from an early age, they are the future leaders. What they learn today, will shape how they turn out to be later when they grow up.

\section{References:}

Anderson, W., \& Groft, P. (1972). A New Look at Children's Literature. Belmont, CA: Wadsworth Publishing Co., Inc.

Applebee, A.N. (1977). A Sense of Story. Theory into Practice, 16-5: 342-347

Bandura, A. (1977). Social Learning Theory. Englewood Cliffs, NJ: Prentice.

Bennet, W. (1995). Books of Virtues. New York: Simon \& Schuster.

Bruner, J. (1986). Actual Minds, Possible Worlds. Cambridge, MA: Harvard University Press,

Cotton, K. (1996). Educating for citizenship. School improvement research series. Available: http://www.nwrel.org/scpd/sirs/10/ c019.html. Retrieved [22 November 2015]

DeVries. R \& Zan B,. (1994). Moral Classroom, Moral Children: Creating a Constructivist Atmosphere in early Education. New York: Teachers College Press.

Di Domenico. (2015). Books that Teach Kids about Democracy. Available: http://www. montrealfamilies.ca/Montreal-Families/ October-2015/Books-that-teachkids-about-democracy/. Retrieved [21 November 2015]

\footnotetext{
32 Cotton, K, Educating for citizenship. (School improvement research series, 1996), Available: http://www.nwrel.org/scpd/sirs/10/c019.html. Retrieved [22 November 2015]
} 
Epp, M., \& Beaulieu, K. (2015). Democracy in the Classroom. In T.A. Horton \& L. Lemisko (Eds). Educator to Educator: Unpacking and Repacking Generative Concepts in Social Studies, 93-104. Rotterdam: Sense Publishers.

Emilson, A. (2011). Democracy Learning in A Preschool Context. In N, Pramling \& I.P. Samuelson (Eds). Educational Encounters: Nordic Studies in Early Childhood Didactics, 157-172. New York: Springer.

Emilson, A., \& Johansson, E. (2009). The Desirable Toddler in Preschool: Values Communicated in Teacher and Child Interactions. In D. Berthelses, J. Brownlee, \& E. Johansson (Eds.), Participatory Learning in The Early Years: Research and Pedagody. New York: Rotledge

Joosen, V. (2005). Fairy-tale Retellings between Art and Pedagogy. Children's Literature in Education, 35-2: 129-139

Karolides, N.J., \& Rosenblatt, L.M. (2005). Theory and Practice: An Interview with Louise M. Rosenblatt. In L. Rosenblatt (Eds), Making Meaning with Texts: Selected Essays. Portsmouth: Heinemann.

Kilpatrick, W., Wolfe, G., \& Wolfe, S.M. (1994). Books that Build Character: A Guide to Tecabing Your Child Moral Values. New York: Touchstone.

Lamb, S. (1993). First Moral Sense: An Examination of the Appearance of Morally Related Behavior in Second Year of Life. Journal of Moral Education, 22:2, 97-109.

McGinn, C. (1997). Ethics, Evil and Fiction. Oxford University Press.

Midgley, C., Feldlaufer, H., \& Eccless, J.S. (1989). Changes in Teacher Efficacy and Student Self- and Task-Related Beliefs During the Transition to Junior High School. Journal of Educational Psychology 81 (2): 247258

Nobes, G., \& Pawson, C. (2003). Children's understanding of Social Rules and Social Status. Merryl-Palmer Quarterly: 49: 1, 77-99
Noddings, N. (2002). Starting from Home: Caring \& Social Policy. Los Angeles: University of California Press

Perkins, D. (1992). Smart Schools: From Training Memories to Educating Minds. Free Press.

Revell, L., \& Arthur, J. (2007). Character Education in Schools and the Education of Teachers. Journal of Moral Education, 36:1, 79-92.

Ricceur, P. (1984). Time and Narrative, 3 vols., trans. Kathleen Blamey and David Pellauer, Chicago: University of Chicago Press

Ross, J.A. (1992). Teacher Efficacy and the Effect of Coaching on Student Achievement. Canadian Journal of Education, 17 (1), 51-65.

Sanchez, T.R. (1998). Using Stories about Heroes to Teach Values. ERIC Clearinghouse for Social Studies/Social Science Education. Available: http://files.eric.ed.gov/ fulltext/ED424190.pdf. Retrieved [18 November 2015]

Weatherford, C.G. (2000). Tales that Teach: Children's Literature and Service Leaning. Columbia: National Dropout Prevention Center.

Beda Politik Picu Suami-Istri Cerai (2014). Available: http://www.tribunnews.com/ pemilu-2014/2014/06/18/beda-politikpicu-suami-istri-cerai. Retrieved [21 November 2015].

Choosing A Child's Book by Children Book Council (1995). Available: http://www. readingrockets.org/article/choosingchilds-book. Retrieved [21 November 2015].

Saat Pasangan Bercerai di Tahun Pemilu Karena Urusan Politik (2013). Available: http:// news.detik.com/berita/2449253/-saatpasangan-bercerai-di-tahun-pemilukarena-urusan-politik. Retrieved [20 November 2015].

Talking Politics: What to Say to Your Kids. Available: http://kidshealth.org/parent/ positive/family/voting_banner.html. Retrieved [20 November 2015]. 
Teaching Children Democratic Citizenship. Available: https://foreverfamilies. byu.edu/Pages/parenting/TeachingChildren-Democratic-Citizenship.aspx. Retrieved [22 November 2015].
Tinggi, Cerai Karena Beda Pandangan Politi (2011). Available: http://www.jpnn. com/read/2011/08/04/99779/Tinggi,Cerai-Karena-Beda-Pandangan-Politik-. Retrieved [21 November 2015]. 